American Journal of Applied Sciences 7 (10): 1291-1299, 2010

ISSN 1546-9239

(C) 2010 Science Publications

\title{
Uptake of Heavy Metals by Jatropha curcas L. Planted in Soils Containing Sewage Sludge
}

\author{
${ }^{1}$ Parisa Ahmadpour, ${ }^{1}$ Azmi Mat Nawi,,${ }^{1,2}$ Arifin Abdu, ${ }^{1,2}$ Hazandy Abdul-Hamid, \\ ${ }^{1}$ Daljit Karam Singh, ${ }^{4}$ Affendy Hassan, ${ }^{1}$ Nik Muhamad Majid and ${ }^{3}$ Shamshuddin Jusop \\ ${ }^{1}$ Department of Forest Management, Faculty of Forestry, \\ ${ }^{2}$ Laboratory of Sustainable Bioresource Management, \\ Institute of Tropical Forestry and Forest Products, \\ ${ }^{3}$ Department of Land Management, Faculty of Agriculture, \\ University Putra Malaysia, 43400 UPM Serdang, Selangor, Malaysia \\ ${ }^{4}$ School of International Tropical Forestry, University Malaysia Sabah, 88999 Sabah, Malaysia
}

\begin{abstract}
Problem statement: The chemical pollution of soil has become a major source of concern and has posed serious health problems within the last few years in many developed nations. A variety of organic and inorganic pollutants, including heavy metals, are being mixed in with the cultivated soil and water. Sewage sludge was one of the major sources of enrichment of heavy metals. These pollutants are eventually transported to the natural vegetation and cultivated crops and concentrated in food chains, with possible detrimental effects on human health and wild-life. Thus, soil contaminants need to be cleaned up to improve environmental safety. Approach: Research was conducted to elucidate the potential of Jatropha curcas L. to clean toxic heavy metals derived from sewage sludge. $J$. curcas seedlings were planted on six different planting media T0 (100\% soil-control), T1 (80\% soil and 20\% sewage sludge), T2 (60\% soil and 40\% sewage sludge), T3 (40\% soil and 60\% sewage sludge), T4 (20\% soil and $80 \%$ sewage sludge) and T5 (100\% sewage sludge) for a period of three months. The growth performance, including height and diameter, of $J$. curcas was measured using diameter tape, while the basal diameter was measured using a venier caliper every two weeks. Plant samples were collected after harvest and soil samples were collected before and after planting. The ICP-MS was used to determine the concentration of heavy metals in the planting medium and plant parts. Results: According to the growth parameters, the composition of $60 \%$ sewage sludge mixed with $40 \%$ soil was suitable for achieving optimum $J$. curcas growth. This plant was able to remove heavy metals $(\mathrm{Zn}, \mathrm{Pb}, \mathrm{Cr}, \mathrm{Cd}$ and $\mathrm{Cu})$ effectively from the medium containing $100 \%$ sewage sludge and after harvesting, the concentrations of $\mathrm{Zn}, \mathrm{Pb}, \mathrm{Cr}, \mathrm{Cd}$ and $\mathrm{Cu}$ in $\mathrm{T} 5(100 \%$ sewage sludge medium) were decreased by $67.7,78.3,77.2,78.5$ and $75.0 \%$, respectively from the initial values. The highest levels of $\mathrm{Zn}\left(29.5 \mathrm{mg} \mathrm{kg}^{-1}\right), \mathrm{Cu}\left(0.44 \mathrm{mg} \mathrm{kg}^{-1}\right)$ and $\mathrm{Cd}\left(8.35 \mathrm{mg} \mathrm{kg}^{-1}\right)$ accumulation were found in the roots, whereas the highest $\mathrm{Pb}$ and $\mathrm{Cr}$ concentrations were observed in the leaves and stem, respectively. Conclusion/Recommendations: The roots of $J$. curcas were found to be suitable for the uptake of heavy metals in sewage sludge, especially $\mathrm{Zn}$. Cr was also adsorbed effectively by the leaves. Thus, J. curcas was a suitable plant to use as a phytoremediator to clean heavy metals, in particular $\mathrm{Zn}$, $\mathrm{Cu}$ and $\mathrm{Cr}$. However, a study determining, the short term effects of the large scale use of sewage sludge on trees /-field crops/-leafy vegetables and environmental its impact needs to be carried out.
\end{abstract}

Key words: Heavy metals, Jatropha curcas, phytoremediation, plant growth, sewage sludge

\section{INTRODUCTION}

Soil pollution, a very important environmental problem, has been attracting considerable public attention over the last few decades. Parts of our world have been contaminated with organic and inorganic pollutants for ages and the pollutants are released into our environment through numerous ways, including oil spills and the production of waste from agricultural and industrial activities (Zubillaga and Lavada, 2008; 
Zubillaga et al., 2008). Environmental pollutants include numerous types of solvents such as Trichloroethylene (TCE), atrazine, Trinitrotoluene (TNT), oil, gasoline, benzene, Polycyclic Aromatic Hydrocarbons (PAHs) and fuel additives (Hong et al., 2001; Batiha et al., 2008). Other than that, plant macronutrients and micronutrients include nitrates and phosphate, $\mathrm{Cr}, \mathrm{Fe}, \mathrm{Mn}, \mathrm{Mo}, \mathrm{Ni}, \mathrm{Zn}$ and $\mathrm{Cu}$ and the nonessential elements such as $\mathrm{As}, \mathrm{Cd}$ and $\mathrm{Hg}$ can be categorized as inorganic pollutants. Bridge (2004) stated that organic and inorganic pollutants greatly impact human health and agricultural productivity and also disrupt the world's ecological biodiversity system. These harmful inorganic pollutants, such as heavy metals in plants, can be eliminated through phytoremediation techniques. In areas with high soil concentrations of minerals, they often are also contaminated with heavy metals. The sources of the enrichment of metal in the soil include sewage sludge, incinerators, fertilizers, urban compost and mining residues (Adhikari et al., 2004; Dobra et al., 2006; Patel and Pandey, 2009).

Sewage sludge can be described as the solid waste products from wastewater treatments, mining residues and agricultural waste. It contains numerous heavy metals that possess characteristics pollutants. Thus, when the metals are released or channeled into the soil, it may cause hazardous effects to the crops and also the consumers who utilize the products produced from the crops. Jones and Johnson (1989); Sánchez et al. (2005) and Zakir et al. (2008) also observed that the heavy metals, such as $\mathrm{Cd}, \mathrm{Mn}$ and $\mathrm{Zn}$, in the soil and plant tissues increased after sewage sludge was applied and contributes to the waterways and soils pollution. Kabata-Pendias and Pendias (2001) determined that $\mathrm{Pb}$, $\mathrm{Cd}, \mathrm{Cr}, \mathrm{Hg}, \mathrm{Zn}$ and $\mathrm{Cu}$ are the most common heavy metal contaminants. These heavy metals, when ingested by humans, may cause several health problems, such as anemia and skin allergies (Yadav et al., 2009).

Therefore, the soil must be cleaned up. Phytoremediation, a green technology, has been used to develop approaches that facilitate the removal of heavy metals from soil into plants that are planted on it. Phytoremediation is the use of vegetation for the in situ or ex situ treatment of contaminated soils, sediments and polluted water to detoxify inorganic and organic metals (Salt et al., 1995; Damian and Damian, 2007; Afkar et al., 2010). Alkorta and Garbisu (2001) found that phytoremediation works by accumulating the metals in certain parts of the plant. However, Hansen and Tjell (1983) indicated that the success of phytoremediation in sludge-amended soils also depends greatly on the type of species being planted and the characteristics of the sludge contents.
In this study, the plant species $J$. curcas L. (Family: Euphorbiaceae) was selected for the study of its efficacy to clean up toxic materials from the sewage sludge promising characteristics, including its robust nature, rapid gestation period and excessive recovery. Anatomically, the plant has a straight trunk with reddish grey bark and is able to grow up to $5 \mathrm{~m}$ tall. The leaves of $J$. curcas are about $6-5 \mathrm{~cm}$ long and 5-7 $\mathrm{cm}$ and are usually crowded at the apex of the twig. Yadav et al. (2009), in their studies on the uptake of $\mathrm{As}, \mathrm{Cr}$ and $\mathrm{Zn}$ by $J$. curcas, concluded that this plant exhibits the ability to recover and reclaim the contaminated soils. Not only does $J$. curcas act as an important alternative biofuel, this plant can grow in diverse types of soil conditions. Furthermore, the study performed by Agamuthu et al. (2010) suggested that $J$. curcas is suitable to be used as a phytoremediator for removing hydrocarbon from contaminated soil. In addition, Chehregani and Malayeri (2007) observed that $J$. curcas has the capability to remove $\mathrm{Cd}$ and $\mathrm{Pb}$. Although some studies of concerning the bioremediation of contaminated soils have carried out, current knowledge regarding the potential phytoremediation of sewage sludge by $J$. curcas is limited. Therefore, this study was undertaken to elucidate the potential of $J$. curcas to clean toxic heavy metals in soils treated with sewage sludge.

\section{MATERIALS AND METHODS}

The study was conducted at the greenhouse at the Faculty of Forestry, University Putra Malaysia ( $2^{\circ} 59^{\prime}$ 18.24 " N latitude and $101^{\circ} 42$ ' $45.45^{\prime \prime}$ E longitude) from April to July 2009. Relative humidity in this area was $65 \%$. The seedlings of the J. curcas mother tree collected by the Malaysia Department of Agriculture, Serdang were germinated from cuttings of the mature stem and planted in polybags $(16.0 \times 16.0 \mathrm{~cm})$. The proportions used for the growing medium for the $J$. curcas seedlings were, soil: organic matter: river sand in a 3:2:1 ratio. The seedlings were transplanted into suitable plastic pots $(32.0 \mathrm{~cm}$ height, $106.0 \mathrm{~cm}$ upper diameter and 69.0 lower diameter) that were filled up with the mixture of soil and sewage sludge after one month.

The Completely Randomized Design (CRD) was used and the pots were labeled according to their compositions: T0-control (100\% soil), T1 (80 soil and $20 \%$ sewage sludge), T2 (60 soil and 40\% sewage sludge), T3 (40 soil and 60\% sewage sludge), T4 (20 soil and $80 \%$ sewage sludge) and T5 (100 sewage sludge). The heights and diameters of the $J$. curcas plants were measured every two weeks during the study 
period with diameter tape, while the basal diameter was measured using a venier caliper every two weeks. Soil samples were collected from each pot before, kept in a standard plastic container after planting and air-dried before physico-chemical analyses. The ICP-MS was used (Sahoo et al., 2009) for analyzing the concentrations of heavy metals in the planting medium and plant parts. Hydrochloric acid $(\mathrm{HCl})$ and nitric acid $\left(\mathrm{HNO}_{3}\right)$ were used as extractants. The sample solutions were analyzed with ICP-MS. Total carbon was determined with conventional method, with a Los on Ignition analyzer and $5 \mathrm{~g}$ of air dried soil were kept in an oven for $8 \mathrm{~h}$ at $550^{\circ} \mathrm{C}$.

The analyses of variance for the growth and heavy metals in the soil, sludge and plant parts were done following the ANOVA technique and the mean values were adjusted using Tukey's test $(\mathrm{p}<0.05)$. A comparison using the Student's t-test at a $5 \%$ level was done to detect any significant differences between samples taken before planting and after harvesting.

\section{RESULTS}

Growth performance of $\boldsymbol{J}$. curcas cultivated in a soil containing sewage sludge: The $J$. curcas planted in the T3 medium had the tallest average height $(8.79 \mathrm{~cm})$, while T2 had the shortest height increment $(6.98 \mathrm{~cm})$. After 12 weeks, the $J$. curcas planted in T4 (20\% soil+ $80 \%$ sewage sludge) showed the largest increment in basal diameter $(3.95 \mathrm{~cm})$ compared to that planted in the $100 \%$ soil medium. The $100 \%$ soil (control) allowed for the highest number of leaves, followed by $\mathrm{T} 2$ and T1. Except for T4 and T5, the leaf numbers increased every week. The $J$. curcas planted in T4 and T5 had less leaves.

General properties of the soils: The particle-size analysis that was carried out to evaluate the soil textural class revealed that only treatment 5 exhibited a clay loam texture, while the other treatments, including the control, showed the same clay soil texture. The soil $\mathrm{pH}$ values before planting and after harvesting were significantly different $(\mathrm{p} \leq 0.05)$; in all five treatments (T1 through $\mathrm{T} 5$ ), the $\mathrm{pH}$ of the soil after harvesting was lower compared to before planting, but; the $\mathrm{pH}$ of the soil after harvesting in the control treatment was slightly higher compared to before planting. In the J. curcas growth medium the highest total carbon level was found in T5 $\left(0.24 \mathrm{~g} \mathrm{~kg}^{-1}\right)$ followed by T4 $\left(0.23 \mathrm{~g} \mathrm{~kg}^{-1}\right)$.

Heavy metal concentrations in $J$. curcas growth medium before planting and after harvesting: The concentrations of heavy metals before planting and after harvesting are shown in Fig. 1-5. The $J$. curcas was found to be able to efficiently remove the heavy metals, such as $\mathrm{Zn}, \mathrm{Pb}, \mathrm{Cr}, \mathrm{Cd}$ and $\mathrm{Cu}$ especially in T5 where the planting medium contained $100 \%$ sewage sludge. The $\mathrm{Zn}$ content of the sewage sludge was $366.23 \mathrm{mg} \mathrm{kg}^{-1}$ before planting in $\mathrm{T} 5$ and after harvesting, the $\mathrm{Zn}$ level was $117.97 \mathrm{mg} \mathrm{kg}^{-1}$ (Fig. 1).

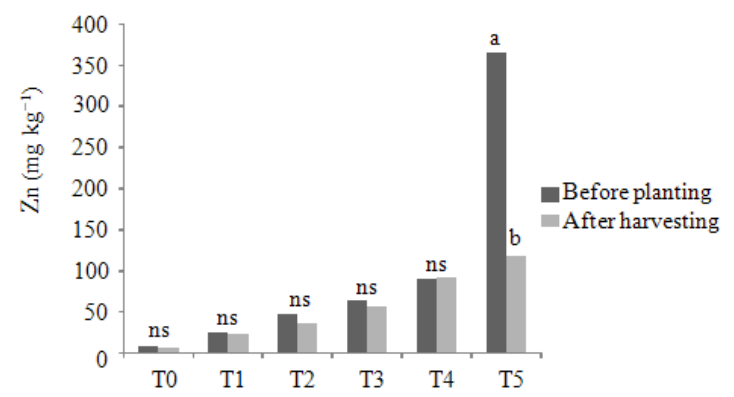

Fig. 1: Concentrations of $\mathrm{Zn}$ in growth medium before planting and after harvesting. Different letters indicate significant difference between means at each treatment before planting and after harvesting according to a Student's t-test $(\mathrm{p}<0.05) \mathrm{ns}$, not significant difference $(\mathrm{p}<0.05)$. T0, (100\% soil-control); T1, (80\% soil and $20 \%$ sewage sludge); T2, (60\% soil and $40 \%$ sewage sludge); T3, $(40 \%$ soil and $60 \%$ sewage sludge); T4, $(20 \%$ soil and $80 \%$ sewage sludge); T5, (100\% sewage sludge)

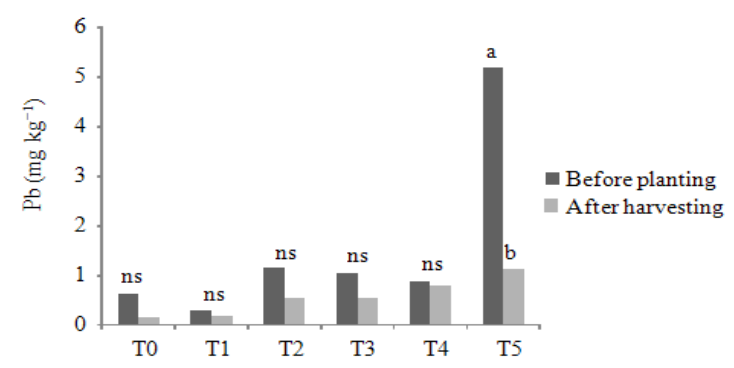

Fig. 2: Concentrations of $\mathrm{Pb}$ in growth medium before planting and after harvesting. Different letters indicate significant difference between means at each treatment before planting and after harvesting according to a Student's t-test $(\mathrm{p}<0.05) \mathrm{ns}$, not significant difference $(\mathrm{p}<0.05)$. T0, (100\% soil-control); T1, (80\% soil and $20 \%$ sewage sludge); T2, (60\% soil and $40 \%$ sewage sludge); T3, (40\% soil and $60 \%$ sewage sludge); T4, (20\% soil and $80 \%$ sewage sludge); T5, (100\% sewage sludge) 
The level of $\mathrm{Pb}$ in $\mathrm{T} 5$ also decreased after harvesting $\left(1.12 \mathrm{mg} \mathrm{kg}^{-1}\right)$ compared to initial Pb level $\left(5.18 \mathrm{mg} \mathrm{kg}^{-1}\right)$ as shown in Fig. 2. The highest decrease in $\mathrm{Cr}$ levels in the $J$. curcas growth medium was observed in T5 in which the level of $\mathrm{Cr}$ after harvesting was $7.69 \mathrm{mg} \mathrm{kg}^{-1}$, while the initial level of $\mathrm{Cr}$ was $33.86 \mathrm{mg} \mathrm{kg}^{-1}$ (Fig. 3).

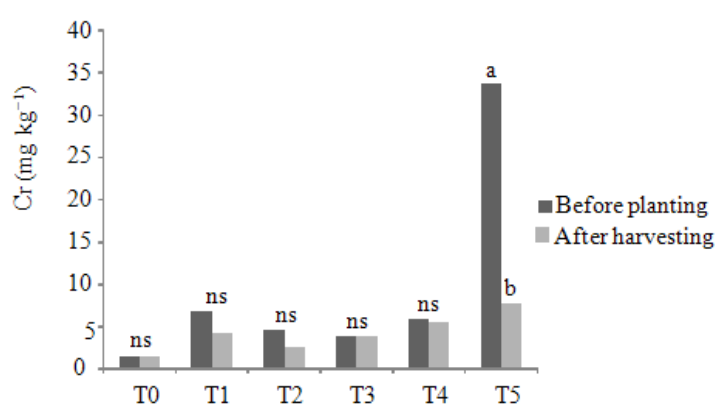

Fig. 3: Concentrations of $\mathrm{Cr}$ in growth medium before planting and after harvesting. Different letters indicate significant difference between means at each treatment before planting and after harvesting according to a Student's t-test $(p<0.05)$ ns, not significant difference $(p<0.05)$. T0, (100\% soil-control); T1, (80\% soil and $20 \%$ sewage sludge); T2, (60\% soil and $40 \%$ sewage sludge); T3, $(40 \%$ soil and $60 \%$ sewage sludge); T4, $(20 \%$ soil and $80 \%$ sewage sludge); T5, (100\% sewage sludge)

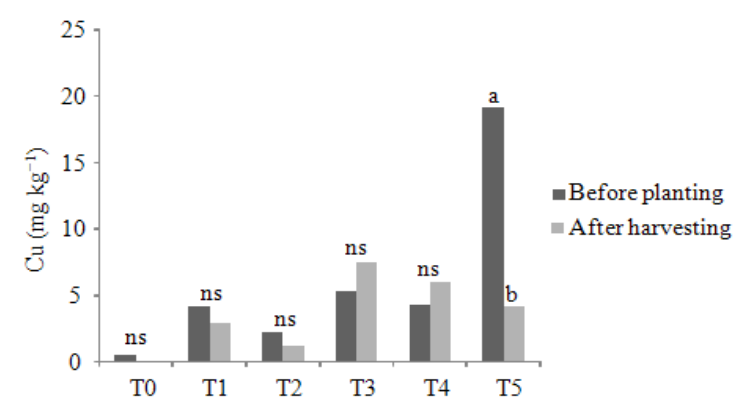

Fig. 4: Concentrations of $\mathrm{Cu}$ in growth medium before planting and after harvesting. Different letters indicate significant difference between means at each treatment before planting and after harvesting according to a Student's t-test $(\mathrm{p}<0.05) \mathrm{ns}$, not significant difference $(\mathrm{p}<0.05)$. T0, (100\% soil-control); T1, (80\% soil and 20\% sewage sludge); T2, (60\% soil and $40 \%$ sewage sludge); T3, $(40 \%$ soil and $60 \%$ sewage sludge); T4, $(20 \%$ soil and $80 \%$ sewage sludge); T5, (100\% sewage sludge)
The initial value of $\mathrm{Cu}$ was $19.18 \mathrm{mg} \mathrm{kg}^{-1}$ and only $4.13 \mathrm{mg} \mathrm{kg}^{-1}$ was found to be left in medium (Fig. 4). Cadmium uptake was also found to be effective in T5, where the initial value was $0.16 \mathrm{mg} \mathrm{kg}^{-1}$ and the final level after harvest was $0.04 \mathrm{mg} \mathrm{kg}^{-1}$ (Fig. 5).

Heavy metal concentrations in plant parts: The concentrations of $\mathrm{Zn}, \mathrm{Pb}, \mathrm{Cr}, \mathrm{Cu}$ and $\mathrm{Cd}$ in plant parts (leaves, stem and roots) at three months after planting are shown in Table 1-3. The highest $\mathrm{Zn}$ accumulation (29.53 mg kg-1) was observed in the roots of $J$. curcas in T5 (Table 3). Furthermore, the roots of $J$. curcas were found to absorb high levels of $\mathrm{Zn}$ compared to the stem and leaves. The accumulation of $\mathrm{Pb}$ was only observed in the leaves of the plants, with the highest level observed in $\mathrm{T} 4\left(4.63 \mathrm{mg} \mathrm{kg}^{-1}\right)$.

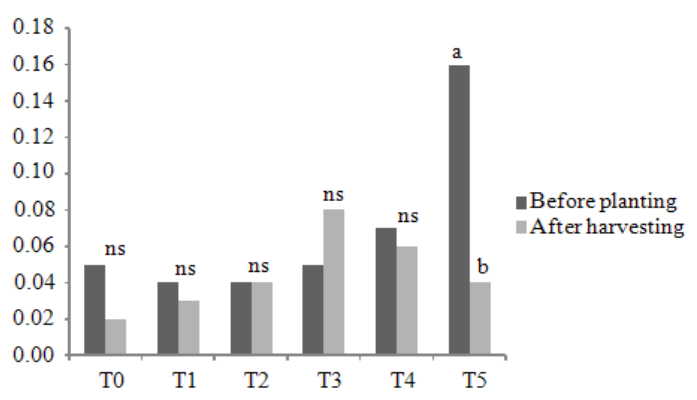

Fig. 5: Concentrations of $\mathrm{Cd}$ in growth medium before planting and after harvesting. Different letters indicate significant difference between means at each treatment before planting and after harvesting according to a Student's t-test $(\mathrm{p}<0.05)$ ns, not significant difference $(\mathrm{p}<0.05)$. T0, (100\% soil-control); T1, $(80 \%$ soil and $20 \%$ sewage sludge); T2, (60\% soil and $40 \%$ sewage sludge); T3, (40\% soil and $60 \%$ sewage sludge); T4, $(20 \%$ soil and $80 \%$ sewage sludge); T5, (100\% sewage sludge)

Table 1:Heavy metal concentrations in leaves of $J$. curcas at three months after planting

\begin{tabular}{|c|c|c|c|c|c|}
\hline \multirow[b]{2}{*}{ Treatment } & \multicolumn{5}{|c|}{ Concentration $\left(\mathrm{mg} \mathrm{kg}^{-1}\right)$} \\
\hline & $\mathrm{Zn}$ & $\mathrm{Pb}$ & $\mathrm{Cr}$ & $\mathrm{Cu}$ & $\mathrm{Cd}$ \\
\hline T0 & $0.42^{\mathrm{d}}$ & $0.06^{\mathrm{d}}$ & $0.01^{\mathrm{a}}$ & $0.06^{\mathrm{a}}$ & nd \\
\hline $\mathrm{T} 1$ & $1.34^{\mathrm{c}}$ & $1.34^{\mathrm{cd}}$ & $0.02^{\mathrm{a}}$ & $0.08^{\mathrm{a}}$ & nd \\
\hline $\mathrm{T} 2$ & $5.04^{\mathrm{a}}$ & $3.27^{\mathrm{b}}$ & $0.03^{\mathrm{a}}$ & $0.09^{\mathrm{a}}$ & nd \\
\hline T3 & $1.97^{\mathrm{a}}$ & $4.05^{\mathrm{ab}}$ & $0.03^{\mathrm{a}}$ & $0.06^{\mathrm{a}}$ & nd \\
\hline $\mathrm{T} 4$ & $4.30^{\mathrm{bc}}$ & $4.63^{\mathrm{a}}$ & $0.04^{\mathrm{a}}$ & $0.09^{\mathrm{a}}$ & nd \\
\hline T5 & $3.147^{\mathrm{b}}$ & $2.51^{\mathrm{c}}$ & $0.02^{\mathrm{a}}$ & $0.08^{\mathrm{a}}$ & nd \\
\hline
\end{tabular}

Note: Different letters within a column indicate significant difference between means at a 5\% level according to Tukey's test, nd: not determined. T0, (100\% soil-control); T1, (80\% soil and $20 \%$ sewage sludge); T2, (60\% soil and 40\% sewage sludge); T3, (40\% soil and $60 \%$ sewage sludge); T4, (20\% soil and $80 \%$ sewage sludge); T5, (100\% sewage sludge) 
Table 2: Heavy metal concentrations in stem of $J$. curcas at three months after planting

\begin{tabular}{llllll}
\hline \multicolumn{5}{c}{ Concentration $\left(\mathrm{mg} \mathrm{kg}^{-1}\right)$} & \\
Treatment & Zn & $\mathrm{Pb}$ & $\mathrm{Cr}$ & $\mathrm{Cu}$ & $\mathrm{Cd}$ \\
\hline T0 & $1.13^{\mathrm{d}}$ & nd & $0.18^{\mathrm{b}}$ & $0.13^{\mathrm{b}}$ & nd \\
T1 & $4.94^{\mathrm{c}}$ & nd & $0.33^{\mathrm{a}}$ & $0.23^{\mathrm{a}}$ & nd \\
T2 & $8.00^{\mathrm{a}}$ & nd & $0.17^{\mathrm{b}}$ & $0.13^{\mathrm{b}}$ & nd \\
T3 & $9.18^{\mathrm{a}}$ & nd & $0.20^{\mathrm{ab}}$ & $0.10^{\mathrm{b}}$ & nd \\
T4 & $5.02^{\mathrm{bc}}$ & nd & $0.15^{\mathrm{b}}$ & $0.16^{\mathrm{ab}}$ & nd \\
T5 & $6.21^{\mathrm{b}}$ & nd & $0.18^{\mathrm{b}}$ & $0.13^{\mathrm{b}}$ & nd \\
\hline
\end{tabular}

Note: Different letters within a column indicate significant difference between means at a 5\% level according to Tukey's test, nd: not determined. T0, (100\% soil-control); T1, (80\% soil and $20 \%$ sewage sludge); T2, (60\% soil and 40\% sewage sludge); T3, (40\% soil and $60 \%$ sewage sludge); T4, (20\% soil and $80 \%$ sewage sludge); T5, (100\% sewage sludge)

Table 3: Heavy metal concentrations in roots of $J$. curcas at three months after planting

\begin{tabular}{llllll}
\hline \multicolumn{5}{c}{ Concentration $\left(\mathrm{mg} \mathrm{kg}^{-1}\right)$} & \\
Treatment & Zn & Pb & $\mathrm{Cr}$ & $\mathrm{Cu}$ & $\mathrm{Cd}$ \\
\hline T0 & $1.02^{\mathrm{e}}$ & nd & $0.09^{\mathrm{a}}$ & $0.20^{\mathrm{b}}$ & $0.00^{\mathrm{d}}$ \\
T1 & $6.48^{\mathrm{d}}$ & nd & $0.12^{\mathrm{b}}$ & $0.16^{\mathrm{bc}}$ & $3.15^{\mathrm{c}}$ \\
T2 & $15.96^{\mathrm{b}}$ & nd & $0.11^{\mathrm{b}}$ & $0.14^{\mathrm{c}}$ & $8.35^{\mathrm{a}}$ \\
T3 & $14.78^{\mathrm{bc}}$ & nd & $0.14^{\mathrm{ab}}$ & $0.22^{\mathrm{b}}$ & $2.03^{\mathrm{c}}$ \\
T4 & $12.40^{\mathrm{c}}$ & nd & $0.11^{\mathrm{b}}$ & $0.44^{\mathrm{a}}$ & $5.13^{\mathrm{b}}$ \\
T5 & $29.53^{\mathrm{a}}$ & nd & $0.18^{\mathrm{a}}$ & $0.32^{\mathrm{ab}}$ & $8.20^{\mathrm{a}}$ \\
\hline
\end{tabular}

Note: Different letters within a column indicate significant difference between means at a 5\% level according to Tukey's test, nd: not determined. T0, (100\% soil-control); T1, (80\% soil and $20 \%$ sewage sludge); T2, (60\% soil and 40\% sewage sludge); T3, (40\% soil and $60 \%$ sewage sludge); T4, (20\% soil and $80 \%$ sewage sludge); T5, (100\% sewage sludge)

The stem of $J$. curcas in the T1 medium accumulated the highest amount of $\mathrm{Cr}\left(0.33 \mathrm{mg} \mathrm{kg}^{-1}\right)$, while the lowest $\left(0.11 \mathrm{mg} \mathrm{kg}^{-1}\right)$ concentration was noted in $\mathrm{T} 4$. The highest $\mathrm{Cu}$ uptake $\left(0.44 \mathrm{mg} \mathrm{kg}^{-1}\right)$ was found in the roots in $\mathrm{T} 4$, followed by $\mathrm{T} 5\left(0.32 \mathrm{mg} \mathrm{kg}{ }^{-1}\right)$ and the minimum $\left(0.06 \mathrm{mg} \mathrm{kg}^{-1}\right)$ concentration was noted in the leaves of the control and T3. Only the root of J. curcas absorbed and accumulated $\mathrm{Cd}$, having the highest value $\left(8.55 \mathrm{mg} \mathrm{kg}^{-1}\right)$ in $\mathrm{T} 2$, followed by $\mathrm{T} 5\left(8.20 \mathrm{mg} \mathrm{kg}^{-1}\right)$, T4 (5.13 $\left.\mathrm{mg} \mathrm{kg}^{-1}\right), \mathrm{T} 1\left(3.15 \mathrm{mg} \mathrm{kg}^{-1}\right)$ and T3 (3.15 mg $\mathrm{kg}^{-1}$ ), while Cd was not present in the control (Table 3).

Relationship between heavy metal concentrations in the soil and plant parts: The highest concentrations of $\mathrm{Zn}, \mathrm{Cu}, \mathrm{Cr}, \mathrm{Pb}$ and $\mathrm{Cd}$ in $100 \%$ sewage sludge contributed to the increased basal area in the T4 and T5 treatments and the height increase in $\mathrm{T} 3$, which consisted of $40 \%$ soil and $60 \%$ sewage sludge and this proportion may have allowed for optimal plant growth stimulation. Efficient $\mathrm{Pb}$ uptake was found in the leaves, having the highest numbers in T4. The high uptake of $\mathrm{Pb}$ in $\mathrm{T} 4$ compared to T5 may actually be the maximum uptake of $\mathrm{Pb}$ that is able to be absorbed by $J$. curcas. Next to $\mathrm{Pb}, \mathrm{Zn}$ was the most prominent heavy metal that was absorbed by $J$. Curcas. The maximum $\mathrm{Zn}$ accumulation was observed in the roots in comparison to the stems and leaves, showing the highest concentration in $\mathrm{T} 5\left(29.53 \mathrm{mg} \mathrm{kg}{ }^{-1}\right)$ and the lowest in the control. The $\mathrm{Cd}$ level was found to be low in the soil before planting and remained lower after the $J$. curcas had been harvested, with the highest uptake of Cd observed in $\mathrm{T} 5\left(0.12 \mathrm{mg} \mathrm{kg}{ }^{-1}\right)$ in the roots, with lesser amounts observed in the stem and leaves. All parts of J. curcas were able to absorb and store $\mathrm{Cr}$, especially the stem, with the highest level of $\mathrm{Cr}$ uptake $\left(0.33 \mathrm{mg} \mathrm{kg}^{-1}\right)$ recorded in $\mathrm{T} 2$. The pattern of $\mathrm{Cu}$ uptake by $J$. curcas was not proportional because the levels of $\mathrm{Cu}$ in the soil after harvest were lower compared to the soil before planting in the control, T1 and T2, while in $\mathrm{T} 3$ and $\mathrm{T} 4$, the levels of $\mathrm{Cu}$ were higher in the soil after $J$. curcas has been harvested compared to before planting.

\section{DISCUSSION}

Growth performance of $\boldsymbol{J}$. curcas and effects of sewage sludge on soil acidity: The highest average height increase $(8.79 \mathrm{~cm})$ was found in T3, while T2 showed the lowest increase in height $(6.98 \mathrm{~cm})$. These results indicate that the composition of $60 \%$ sewage mixed with $40 \%$ soil is suitable and ideal for achieving optimum $J$. curcas growth. The $J$. curcas planted in $\mathrm{T}_{4}$ showed the highest increase in basal diameter $(3.95 \mathrm{~cm})$ compared to that planted in the $100 \%$ soil medium. The growth or increase in the basal diameter of $J$. curcas was found to be slow in the first 2 weeks, which likely occurred due to the plants attempting to acclimatize themselves to their new growing medium. The highest number of leaves was observed in the $100 \%$ soil medium (control), followed by $\mathrm{T} 2$ and $\mathrm{T} 1$. With the exception of $\mathrm{T} 4$ and $\mathrm{T} 5$, the numbers of leaves increased every week. The $J$. curcas planted in T4 and T5 had less leaves, which may have been caused by the high heavy metal level in the soil, creating an acidic state in the growing medium.

Heavy metal concentrations in $J$. curcas growth medium: J. curcas can uptake heavy metals such as $\mathrm{Zn}, \mathrm{Pb}, \mathrm{Cr}, \mathrm{Cd}$ and $\mathrm{Cu}$ efficiently, especially in $\mathrm{T} 5$, in which the planting medium contained $100 \%$ sewage sludge (Table 1). Before planting, the concentrations of $\mathrm{Cd}, \mathrm{Cu}$ and $\mathrm{Pb}$ in the sewage-sludge containing soils were within- the permissible limits stated by World Health Organization (1998), except for $\mathrm{Zn}$, which showed levels of $366.23 \mathrm{mg} \mathrm{kg}^{-1}$ before planting in $\mathrm{T} 5$. The $\mathrm{Zn}$ level from the $\mathrm{T} 5$ harvest was $117.97 \mathrm{mg} \mathrm{kg}^{-1}$, 
showing a $67.7 \%$ decrease compared to the initial level. The level of $\mathrm{Pb}$ in $\mathrm{T} 5$ also showed the highest decrease compared to the other treatments and control medium, with $78.37 \%$ less in the growth medium after harvesting $\left(5.18 \mathrm{mg} \mathrm{kg}^{-1}\right)$ compared to the initial $\mathrm{Pb}$ level $(1.12$ $\mathrm{mg} \mathrm{kg}^{-1}$ ). The success of $J$. curcas in taking up $\mathrm{Pb}$ and $\mathrm{Cd}$ from soil is paralleled with the capacities of Euphorbia cheinrandenia, which comes from the same family (Chehregani and Malayeri, 2007). The highest decrease in $\mathrm{Cr}$ levels in the $J$. curcas growth medium was observed in $\mathrm{T} 5$, in which the level of $\mathrm{Cr}$ after harvesting was $7.69 \mathrm{mg} \mathrm{kg}^{-1}$, while the initial level was $33.86 \mathrm{mg} \mathrm{kg}^{-1}$, indicating a $77.19 \%$ loss. The initial value of $\mathrm{Cu}$ was $19.18 \mathrm{mg} \mathrm{kg}^{-1}$ and only $4.13 \mathrm{mg} \mathrm{kg}^{-1}$ remained in the medium. Cadmium uptake was also found to be effective in T5, where the initial level was $0.16 \mathrm{mg} \mathrm{kg}^{-1}$ and the final level after harvesting was $0.04 \mathrm{mg} \mathrm{kg}^{-1}$ (75.0\% decrease from the initial value).

Treatment 5 exhibited a clay loam texture, while the other treatments, including the control, had a clay soil texture; these results indicated that the soil was clay in nature. Before planting and after harvesting, the $\mathrm{pH}$ value was significantly different $(p \leq 0.05)$ in all treatments. (T1 through $\mathrm{T} 5$ ); the $\mathrm{pH}$ of the soil after harvesting was lower compared to before planting. However, the control treatment showed a slightly higher $\mathrm{pH}$ after harvesting compared to before planting. The greatest decrease in soil $\mathrm{pH}$ levels after planting was observed in T4. The availability of sewage sludge in the soil contributes to a lower soil $\mathrm{pH}$, the highest total carbon level was found in the $J$. curcas growth medium in $\mathrm{T} 5\left(0.24 \mathrm{~g} \mathrm{~kg}^{-1}\right)$ followed by $\mathrm{T} 4(0.23 \mathrm{~g}$ $\left.\mathrm{kg}^{-1}\right)$. The nature of the sewage sludge and the rate of decomposition of the organic materials affect the time necessary to release certain heavy metals into the soil and thus help to improve soil fertility (Rice, 2009).

Heavy metal concentrations in plant parts: The highest $\mathrm{Zn}$ accumulation $\left(29.53 \mathrm{mg} \mathrm{kg}^{-1}\right)$ was recorded in $J$. curcas in T5 (Table 2). Furthermore, the roots of $J$. curcas were found to absorb high levels of $\mathrm{Zn}$ compared to the stems and leaves. $\mathrm{Pb}$ accumulation was only found in the leaves of the plants, with the highest level observed in $\mathrm{T} 4\left(4.63 \mathrm{mg} \mathrm{kg}{ }^{-1}\right)$. The $J$. curcas is not a good $\mathrm{Pb}$ accumulator because it absorbs very small amounts of it in comparison to the other elements. The stem of $J$. curcas in the T1 medium exhibited the highest $\mathrm{Cr}\left(0.33 \mathrm{mg} \mathrm{kg}{ }^{-1}\right)$ accumulation, while the lowest $\left(0.11 \mathrm{mg} \mathrm{kg}^{-1}\right)$ was noted in $\mathrm{T} 4$. The highest $\mathrm{Cu}$ uptake $\left(0.44 \mathrm{mg} \mathrm{kg}^{-1}\right)$ was found in the roots in $\mathrm{T} 4$, followed by $\mathrm{T} 5\left(0.32 \mathrm{mg} \mathrm{kg}^{-1}\right)$ and the minimum $(0.06$ $\mathrm{mg} \mathrm{kg}^{-1}$ ) was noted in the leaves of the control and T3.
Only the root of $J$. curcas absorbed and accumulated $\mathrm{Cd}$, showing the highest concentration $\left(8.55 \mathrm{mg} \mathrm{kg}^{-1}\right)$ in $\mathrm{T} 2$, followed by $\mathrm{T} 5\left(8.20 \mathrm{mg} \mathrm{kg}{ }^{-1}\right), \mathrm{T} 4(5.13 \mathrm{mg}$ $\left.\mathrm{kg}^{-1}\right)$, T1 (3.15 mg kg$)$ and T3 (3.15 $\left.\mathrm{mg} \mathrm{kg}^{-1}\right)$, while the control contained negligible amounts of $\mathrm{Cd}$ concentration was.

Relationship between heavy metal concentrations in the growth medium and plant parts: The higher concentrations of $\mathrm{Zn}, \mathrm{Cu}, \mathrm{Cr}, \mathrm{Pb}$ and $\mathrm{Cd}$ in the $100 \%$ sewage sludge contributed to increased basal area in the T4 and T5 treatments and the height increase in T3, which consisted of $40 \%$ soil and $60 \%$ sewage sludge, this proportion may have allowed for optimal plant growth stimulation. Yadav et al. (2009) reported that the soil or sewage sludge containing higher amounts of $\mathrm{Zn}$ compared to the other metals tended to reduce the increase in plant growth. Similar results were also observed in T5 treated $J$. curcas where the growth quite slow or poor compared to other $J$. curcas, in which the growth markedly slowed compared to the J. curcas planted in the lower proportions of sewage sludge. Moreover, Cooke and Johnson (2002) found that low nutrient and water holding capacities, toxic substances, salinity, stability, nutrient deficiencies (especially N, P and $\mathrm{K}$ ), poor physical properties and excess acidity and alkalinity are some of the contributing factors that inhibit or disrupt plant growth in soil containing high amounts of heavy metals. Macnair (1987) and Baker (1987) reported that the $J$. curcas plant has the capability to grow well in soil with high heavy metals concentrations of heavy metals. The higher uptake of $\mathrm{Pb}$ in $\mathrm{T} 4$ compared to $\mathrm{T} 5$ may actually be the maximum uptake of $\mathrm{Pb}$ that was able to be absorbed by J. curcas. Next to $\mathrm{Pb}, \mathrm{Zn}$ was the most prominent heavy metal that was absorbed by J. Curcas. The maximum $\mathrm{Zn}$ accumulation was observed in the roots in comparisons to the stems and leaves, with the highest concentrations in $\mathrm{T} 5\left(29.53 \mathrm{mg} \mathrm{kg}^{-1}\right)$ and the lowest in the control. Baker (1981) reported that some plants are able to hasten the transportation of heavy metals from their roots to shoots, which may be related to the rate of $\mathrm{Zn}$ uptake by $J$. curcas. Similarly, the restriction of heavy metals in $J$. curcas also affects the uptake of $\mathrm{Cd}$. The $\mathrm{Cd}$ level was found to be low in the soil before planting and remained low after $J$. curcas been harvested, with the highest uptake of $\mathrm{Cd}$ observed in $\mathrm{T} 5\left(0.12 \mathrm{mg} \mathrm{kg}^{-1}\right)$ in the roots and the stems and leaves to a lesser degree; this finding was supported by Keller et al. (2003), who illustrated that plants with extensive root systems have the advantage of being able to absorb greater amounts of heavy metals due to better soil penetration. 
Regarding the potential use of $J$. curcas for the phytoremediation of coal fly ash, we have discerned that $J$. curcas is very efficient in accumulating heavy metals, causing no damaging effects to the root biomass. J. curcas was also found to be effective in taking up $\mathrm{Cr}$ from the soil. All parts of $J$. curcas were able to absorb and store $\mathrm{Cr}$, especially the stems, which showed the highest levels of $\mathrm{Cr}$ uptake $\left(0.33 \mathrm{mg} \mathrm{kg}^{-1}\right)$ in T2. The pattern of $\mathrm{Cu}$ uptake by $J$. curcas was not proportional because the $\mathrm{Cu}$ levels in the soil after harvesting were lower compared to soil before planting in the control, $\mathrm{T} 1$ and $\mathrm{T} 2$, while in $\mathrm{T}_{3}$ and $\mathrm{T}_{4}$, the levels of $\mathrm{Cu}$ were higher in the soil after $J$. curcas has been harvested compared to before planting. Alkorta and Garbisu (2001) found that the plant metabolites of the pollutant may be more toxic compared to the original environmental pollutant. The accumulation of heavy metals in $J$. curcas tends to occur mainly in the roots and to a lesser degree in the leaves and stems. Palmroth et al. (2002) also agreed that plant roots stimulate the degradation of toxic organic materials. Furthermore, roots act as a medium for soil microorganisms to speed up the organic pollutant biodegradation rates. Therefore, the efficiency of heavy metal uptake by plant parts is as follows:

$$
\text { stem }<\text { leaves }<\text { roots }
$$

\section{CONCLUSION}

The roots of $J$. curcas were found to be suitable for taking up heavy metals from sewage sludge, especially $\mathrm{Zn}$. Cr was found to be effectively absorbed by the leaves of $J$. curcas. In a nutshell, $J$. curcas is a suitable plant to use as a phytoremediator due its ability to accumulate high levels heavy metals in sewage sludge, especially $\mathrm{Zn}, \mathrm{Cu}$ and $\mathrm{Cr}$. Nevertheless, phytoremediation encompasses a much broader model and thus, additional more lengthy studies are needed to support the claim that $J$. curcas is a hyper-accumulator of heavy metals. An evaluation of the short-term effects the large-scale use of sewage sludge on tree growth and the environment also needs to be carried out.

\section{ACKNOWLEDGEMENT}

This research was financially supported by a Fundamental Research Grant Scheme (FRGS) from the Ministry of Higher Education of Malaysia (MOHE) through the University Putra Malaysia, Malaysia (UPM). We thank Ms. Zarina Abdul Rahman and Mr. Ariffin Abu Hassan for their kind assistance during the laboratory analysis at the laboratory of Soil Science,
Faculty of Forestry and Faculty of Agriculture, University Putra Malaysia. We also acknowledge the Indah Water Konsortium (IWK) for their permission to use the sewage sludge in this study.

\section{REFERENCES}

Adhikari, T., M.C. Manna, M.V. Singh and R.H. Wanjari, 2004. Bioremediation measure to minimize heavy metals accumulation in soils and crops irrigated with city effluent. J. Food Agric. Environ., 2: 266-270. http://www.worldfood.net/scientficjournal/2004/issue1/abstracts/abst ract48.php

Afkar, E., H. Ababna and A.A. Fathi, 2010. Toxicological response of the green alga Chlorella vulgaris, to some heavy metals. Am. J. Environ. Sci., 6: 230-237. http://www.scipub.org/fulltext/ajes/ajes63230237.pdf

Agamuthu, P., O.P. Abioye and A.A. Aziz, 2010. Phytoremediation of soil contaminated with used lubricating oil using Jatropha curcas. J. Hazard. Mater., 179: 891-894. DOI: 10.1016/j.jhazmat.2010.03.088

Alkorta, I. and C. Garbisu, 2001. Phytoremediation of organic contaminants in soils. Bioresour. Technol., 79: 273-276. DOI: 10.1016/S0960-8524(01)00016-5

Aravind, P. and M.N.V. Prasad, 2004. Zinc protects chloroplasts and associated photo-chemical functions in cadmium exposed Ceratphyllum demersum (L.) a fresh water macrophyte. Plant Sci., 166: 1321-1327. DOI: 10.1016/j.plantsci.2004.01.011

Baker, A.J.M., 1981. Accumulators and excludersstrategies in the response of plants to heavy metals. J. Plant Nutr., 3: 643-654. DOI: 10.1080/01904168109362867

Baker, A.J.M., 1987. Metal tolerance. New Phytol., 106: 93-111. http://www.jstor.org/stable/2433013

Batiha, M.A., A.A.H. Kadhum, A.B. Mohamad, M.S. Takriff and Z. Fisal et al., 2008. MAM-an aquivalence-based dynamic mass balance model for the fate of non-volatile organic chemicals in the agricultural environment. Am. J. Eng. Applied Sci., 1 : 252-259. http://www.scipub.org/fulltext/ajeas/ajeas14252259.pdf

Bridge, G., 2004. Contested terrain: Mining and the environment. Ann. Rev. Environ. Resour., 29: 205-259. DOI: 10.1146/annurev.energy.28.011503.163434 
Chehregani, A. and B.E. Malayeri, 2007. Removal of heavy metals by native accumulator plants. Int. J. Agric. $\quad$ Biol., $\quad$ 9: 462-465. http://www.fspublishers.org/ijab/pastissues/IJABVOL_9_NO_3/18.pdf

Cooke, J.A. and M.S. Johnson, 2002. Ecological restoration of land with particular reference to the mining of metals and industrial minerals; a review of theory and practice. Environ. Rev., 10: 41-71. DOI: $10.1139 / \mathrm{a} 01-014$

Damian, F. and G. Damian, 2007. Detoxification of heavy metal contaminated soils. Am. J. Environ. Sci., $\quad 3$ 193-198. http://www.thescipub.com/abstract/10.3844/ajessp. 2007.193.198

Dobra, M., V. Viman and G. Vâtcă, 2006. Contributions to the study of heavy metals concentration variation in sedimentable dusts according to the distance from the pollution source. Am. J. Environ. Sci., 2: 92-94. http://www.thescipub.com/abstract/10.3844/ajessp. 2006.92.94

Hansen, J.A. and J.C. Tjell, 1983. Sludge Application to Land-Overview of Cadmium Problem. In: Environmental Effect of Organic and Inorganic Contaminants in Sewage Sludge, Davis, R.D., G. Hucker and P. L'Hermite (Eds.). Reidel Publishing Company, Dordrecht, pp: 137-146.

Hong, M.S., W.F. Farmayan, I.J. Dortch, C.Y. Chiang and S.K. McMillan et al., 2001. Phytoremediation of MTBE from a groundwater plume. Environ. Sci. Technol., 35: 1231-1239. PMID: 11347938

Jones, K.C. and A.E. Johnston, 1989. Cadmium in cereal grain and herbage from long-term experimental plots at Rothamsted, UK. Environ. Pollut., 57: 199-216. DOI: 10.1016/02697491(89)90012-2

Kabata-Pendias, A. and H. Pendias, 2001. Trace Elements in the Soil and Plants. 3rd Edn., CRC Press, Boca Raton, FL., ISBN: 0849315751, pp: 413.

Keller, C., D. Hammer, A. Kayser, W. Richner and M. Brodbeck et al., 2003. Root development and heavy metal phytoextraction efficiency: Comparison of different plant species in the field. Plant Soil, 249: 67-81. DOI: 10.1023/A:1022590609042

Macnair, M.R., 1987. Heavy metal tolerance in plants: A model evolutionary system. Trends Ecol. Evolut., 2: 354-359. DOI: 10.1016/01695347(87)90135-2
Palmroth, M.R.T., J. Pitchel and J.A. Puhakka, 2002. Phytoremediation of subarctic soil contaminated with diesel fuel. Bioresour. Technol., 84: 221-228. DOI: 10.1016/S0960-8524(02)00055-X

Patel, H. and S. Pandey, 2009. Exploring the reuse potential of chemical sludge from textile wastewater treatment plants in India-A hazardous waste. Am. J. Environ. Sci., 5: 106-110. http://www.scipub.org/fulltext/ajes/ajes51106110.pdf

Rice, C.W., 2009. Storing carbon in soil: Why and how? American Geological Institute. http://www.geotimes.org/jan02/feature_carbon.htm l\#author

Sánchez, M.E., I.B. Estrada, O. Martínez, A. Aller and A. Morán, 2005. Influence of the application of sewage sludge and presence of pesticides on the development of the microbial population of the soil and on the transformation of organic carbon and nutrient elements. Am. J. Environ. Sci., 1: 172-178. http://www.scipub.org/fulltext/ajes/ajes12172178.pdf

Salt, D.E., M. Blaylock, N.P. Kumar, V. Dushenkov and B.D. Ensley et al., 1995. Phytoremediation: A novel strategy for the removal of toxic metals from the environment using plants. Biotechnology, 13: 468-474. PMID: 9634787

Sahoo, B.K., B.P. Das and D. Mukherjee, 2009. Relativistic coupled-cluster studies of ionization potentials, lifetimes and polarizabilities in singly ionized calcium. Phys. Rev. A, 79: 1-9. DOI: 10.1103/PhysRevA.79.052511

World Health Organization, 1998. Quality Control Methods for Medicinal Plant Materials. 1st Edn., World Health Organization, Geneva, Switzerland, ISBN: 10: 9241545100, pp: 115.

Yadav, S.K., A.A. Juwarkar, G.P. Kumar, P.R. Thawale and S.K. Singh et al., 2009. Bioaccumulation and phyto-translocation of arsenic, chromium and zinc by Jatropha curcas L.: Impact of dairy sludge and biofertilizer. Bioresour. Technol., 100: 4616-4622. DOI: 10.1016/j.biortech.2009.04.062

Zakir, H.M., N. Shikazono and K. Otomo, 2008. Geochemical distribution of trace metals and assessment of anthropogenic pollution in sediments of Old Nakagawa River, Tokyo, Japan. Am. J. Environ. Sci., 4: 654-665. DOI: http://www.scipub.org/fulltext/ajes/ajes46654665.pdf 
Am. J. Applied Sci., 7 (10): 1291-1299, 2010

Zubillaga, M.S. and R.S. Lavado, 2008. Accumulation and movement of four potentially toxic elements in soils throughout five years, during and after biosolid application. Am. J. Environ. Sci., 4: 576-582. http://www.scipub.org/fulltext/ajes/ajes46576582.pdf
Zubillaga, M.S., E. Bressan and R.S. Lavado, 2008. Heavy metal mobility in polluted soils: Effect of different treatments. Am. J. Environ. Sci., 4: 620-624. http://www.scipub.org/fulltext/ajes/ajes46620-624.pdf 